\title{
Herbivore-induced infochemicals influence foraging behaviour in two intertidal predators
}

Ross A. Coleman • Sorain J. Ramchunder •

Kelly M. Davis • A. John Moody • Andrew Foggo

Published online: 4 May 2007

(C) Springer-Verlag 2007

Erratum to: Oecologia 151:454-463

DOI 10.1007/s00442-006-0601-2

Due to an unfortunate error, the name of the third author was printed with error. The correct author list is given here:

Ross A. Coleman, Sorain J. Ramchunder, Kelly M. Davis, A. John Moody, Andrew Foggo

The online version of the original article can be found at http://dx.doi.org/10.1007/s00442-006-0601-2.

R. A. Coleman $(\bowtie) \cdot$ S. J. Ramchunder · K. M. Davis ·

A. J. Moody · A. Foggo

Marine Biology and Ecology Research Centre,

School of Biological Sciences, University of Plymouth,

Plymouth PL4 8AA, UK

e-mail: rcoleman@usyd.edu.au

Present Address:

R. A. Coleman

Centre for Research on Ecological Impacts of Coastal Cities,

Marine Ecology Laboratories A11, The University of Sydney,

Sydney, NSW 2006, Australia 